\title{
UNDERSTANDING TISSUE-ENGINEERED ENDOCHONDRAL OSSIFICATION; TOWARDS IMPROVED BONE FORMATION
}

\author{
C. Knuth ${ }^{1}$, C. Kiernan², E. Wolvius ${ }^{1}$, R. Narcisi ${ }^{3}$ and E. Farrell ${ }^{1, *}$ \\ ${ }^{1}$ Department of Oral and Maxillofacial Surgery, Orthodontics and Special Dental Care, Erasmus MC, \\ University Medical Centre Rotterdam, Rotterdam, the Netherlands \\ ${ }^{2}$ Department of Immunology, Erasmus MC, University Medical Centre Rotterdam, \\ Rotterdam, the Netherlands \\ ${ }^{3}$ Department of Orthopaedics, Erasmus MC, University Medical Centre Rotterdam, \\ Rotterdam, the Netherlands
}

\begin{abstract}
Endochondral ossification (EO) is the process by which the long bones of the body form and has proven to be a promising method in tissue engineering for achieving cell-mediated bone formation. The present review centred on state-of-the-art research pertaining to mesenchymal stem cells (MSCs)-mediated endochondral bone formation, focusing on the role of donor cells, extracellular matrix and host immune cells during tissue-engineered bone formation. Possible research avenues to improve graft outcome and bone output were highlighted, as well as emerging research that, when applied to tissue-engineered bone grafts, offers new promise for improving the likelihood of such grafts transition from bench to bedside.
\end{abstract}

Keywords: Endochondral ossification, bone tissue engineering, regenerative medicine, mesenchymal stem cell differentiation, extracellular matrix, vascularisation, collagen type $\mathrm{X}$, immune system.

*Address for correspondence: Eric Farrell B.A. Mod. Physiol, PhD, Principal Investigator Bone Tissue Engineering Research Group, Department of Oral and Maxillofacial Surgery, Special Dental Care and Orthodontics, Erasmus University Medical Centre Rotterdam, Postbox 2040, 3000 CA Rotterdam, the Netherlands.

Telephone number: +31 107043655 Email: e.farrell@erasmusmc.nl

Copyright policy: This article is distributed in accordance with Creative Commons Attribution Licence (http://creativecommons.org/licenses/by-sa/4.0/).

\begin{tabular}{|c|c|c|c|}
\hline & List of Abbreviations & $\begin{array}{l}\text { HMGB1 } \\
\text { HSPG }\end{array}$ & $\begin{array}{l}\text { high mobility group box } 1 \\
\text { heparin sulphate proteoglycan }\end{array}$ \\
\hline ALP & alkaline phosphatase & Ihh & Indian hedgehog homologue \\
\hline ANG1 & angiopoietin 1 & $\mathrm{IL}$ & interleukin \\
\hline BMP2 & bone morphogenetic protein 2 & IMO & intramembranous ossification \\
\hline CCN2 & $\begin{array}{l}\text { cellular communication network } \\
\text { factor } 2\end{array}$ & $\begin{array}{l}\mathrm{KO} \\
\mathrm{MHC}\end{array}$ & $\begin{array}{l}\text { knock-out } \\
\text { major histocompatibility complex }\end{array}$ \\
\hline COLX & collagen type $X$ & MMPs & matrix metalloproteinases \\
\hline CTACK & $\begin{array}{l}\text { cutaneous T-cell attracting } \\
\text { chemokine }\end{array}$ & MSC & $\begin{array}{l}\text { mesenchymal stem cell/marrow } \\
\text { stromal cell }\end{array}$ \\
\hline CTGF & connective tissue growth factor & NK & natural killer \\
\hline DCs & dendritic cells & PDGFA & platelet-derived growth factor \\
\hline ECM & extracellular matrix & & subunit $\mathrm{A}$ \\
\hline $\mathrm{EO}$ & endochondral ossification & PLGA & poly(D,L-lactic-co-glycolic acid) \\
\hline FGF & fibroblast growth factor & PRP & platelet-rich plasma \\
\hline GAG & glycosaminoglycan & PTHrP & parathyroid hormone-related \\
\hline GDF5 & growth and differentiation factor 5 & & protein \\
\hline hPLAP & $\begin{array}{l}\text { human placental alkaline } \\
\text { phosphatase }\end{array}$ & RANKL & $\begin{array}{l}\text { receptor activator of nuclear factor } \\
\text { kappa-B ligand }\end{array}$ \\
\hline
\end{tabular}




$\begin{array}{ll}\text { Runx2 } & \begin{array}{l}\text { runt-related transcription factor } 2 \\ \text { Schmid metaphyseal } \\ \text { chondrodysplasia disorder } \\ \text { tissue engineering and regenerative } \\ \text { medicine } \\ \text { transgenic }\end{array} \\ \text { Tg } & \text { transforming growth factor } \\ \text { TGF } & \text { tumour necrosis factor alpha } \\ \text { TNF } \alpha & \text { vascular endothelial growth factor } \\ \text { VEGF } & \text { wingless-type MMTV integration } \\ \text { WNT } & \text { site family }\end{array}$

\section{Introduction}

Bone has an inherent ability to repair itself following small injuries (Schindeler et al., 2008). However, when a critical-size defect exists, or is created following surgery, the bone regenerative capacity is exhausted, making clinical intervention necessary. As a result, bone is one of the most commonly transplanted tissues in the world (Petite et al., 2000). Autologous bone grafts are the current gold-standard treatment option for such defects as they are a natural osteoinductive/osteoconductive material (Frohlich et al., 2008; Lieberman and Friedlaender, 2005) with low risk of immune rejection (Bauer and Muschler, 2000). Although roughly $90 \%$ of autologous grafts are considered to be successful (Bauer and Muschler, 2000; Hayden et al., 2012), their use is limited due to the availability of harvestable material, uncertain integration following implantation and risk of donor site morbidity (Bauer and Muschler, 2000). Although allogeneic and xenogeneic grafts are available, they are associated with other risks, including disease transfer or immunological rejection (Gómez-Barrena et al., 2015). Common complications associated with bone grafts - regardless if autologous, allogeneic or xenogeneic - include insufficient vascularisation at the implant site, leading to poor nutrient/oxygen delivery, cell death and core necrosis (Frohlich et al., 2008; Lieberman and Friedlaender, 2005). This highlights a clear and present need for new suitable graft alternatives.

TERM-based approaches to bone repair vary greatly (Grskovic et al., 2012). Bioactive or inert materials (Table 1), which should enhance bone regeneration by guided tissue regeneration, are currently being developed. Although promising, many of these materials and other TERM approaches also rely on the use of iliac crest bone, which does not address the many issues surrounding the use of autologous bone. The use of various adult progenitor cells to create cell-based alternatives recapitulating one of the developmental pathways of bone formation to achieve bone regeneration and repair of critical-size bone defects has received much attention in recent decades. This review focuses on the state-of-the-art strategies implemented in cell-based TERM and on considerations for improved bone regeneration and output.

\section{Cell-based strategies for bone repair; endochondral vs. intramembranous ossification}

Bone develops through either IMO (Kim et al., 2011) or EO (Shapiro, 2008; Yang et al. 2009). IMO involves the direct differentiation of mesenchymal cells to osteoblasts, the process by which most facial bones are formed (Thompson et al., 2002). IMO can be achieved in TERM by either direct differentiation or through the combination of MSCs with biomaterials (including, but not limited to, tricalcium phosphate or collagen sponges) (Meijer et al., 2008). Although promising, this approach has not reached its full potential due to insufficient vascularisation of the implant, resulting in core necrosis (Chatterjea et al., 2010; Meijer et al., 2008). Vascularisation is crucial for graft survival and is required for proper integration with the patient's existing bones. Instead, EO is a more promising model for bone formation as it naturally induces vascularisation at the implant site (Cervantes-Diaz et al., 2017; Gawlitta et al., 2010; Mackie et al., 2008; Medici and Olsen, 2012; Thompson et al., 2015; Yeung Tsang et al., 2014).

EO relies on the establishment of a cartilage template, which is achieved by condensation and differentiation of mesenchymal cells (Mackie et al. 2008). Chondrocytes within the template exhibit a zonal distribution, with clear divisions between the different stages of chondrocyte differentiation within the template. Resting chondrocytes display a seemingly sporadic distribution and are thought to maintain a population of cells which, when triggered, give rise to the more organised, disk-like proliferating chondrocytes (Schrier et al., 2006; Yang et al., 2003). Proliferating chondrocytes contribute to longitudinal bone growth and are regulated by a complicated feedback loop, including factors such as TGF $\beta$, PTHrP and Ihh (Chen et al., 2008; Kronenberg et al., 2003). These factors are also involved in initiating hypertrophic differentiation. When hypertrophic differentiation starts, chondrocytes secrete factors to recruit other cell types critical for successful EO (Ballock et al., 2003; Kronenberg et al., 2003) (Fig. 1). For example, factors such as ANG-1, PDGFA and VEGF will aid in the recruitment of the nearby vasculature to the cartilage template (Colnot et al., 2001), which will ultimately result in the delivery of pre-osteoblastic cells to the cartilage template (Maes et al., 2010). Factors released by the hypertrophic chondrocytes, including MMPs and other proteolytic enzymes, will contribute to early matrix remodelling (Nishimura et al., 2012); release of RANKL and VEGF will recruit osteoclasts, which further contribute to proper matrix remodelling (Engsig et al., 2000). Together, osteoblasts delivery through the invaded vasculature, trans-differentiation of chondrocytes in the cartilage template and osteoblast invasion from the surrounding bone collar calcify the cartilage matrix and bone formation occurs (Maes et al., 2010; Yang et al., 2014). The coordination of these events with cell/ vascular recruitment ultimately controls effective 
Table 1. Bone-graft-related terminology and definitions/examples.

\begin{tabular}{|c|c|c|}
\hline Term & Definition & Reference \\
\hline $\begin{array}{l}\text { Osteoinductive } \\
\text { material }\end{array}$ & $\begin{array}{l}\text { Can induce osteogenic differentiation of primitive cells; } \\
\text { induces bone formation. Process that is observed during } \\
\text { bone repair (healing). }\end{array}$ & $\begin{array}{l}\text { Finkemeier, } 2002 \\
\quad \text { Lee, } 2016\end{array}$ \\
\hline $\begin{array}{l}\text { Osteoconductive } \\
\text { material }\end{array}$ & $\begin{array}{l}\text { Causes bone formation on the surface of a material; induces } \\
\text { migration of bone-forming cells to the surface of the } \\
\text { material; observed regularly on bone implants; examples: } \\
\text { hydroxyapatite, tricalcium phosphate. }\end{array}$ & $\begin{array}{l}\text { Finkemeier, } 2002 \\
\quad \text { Lee, } 2016\end{array}$ \\
\hline Inert material & $\begin{array}{l}\text { Not chemically active; material does not join/integrate } \\
\text { directly with bone; example: titanium, steel. }\end{array}$ & $\begin{array}{l}\text { LeGeros, } 2008 \\
\text { Roselló Llabrés et al., }\end{array}$ \\
\hline $\begin{array}{l}\text { Bioactive } \\
\text { material }\end{array}$ & $\begin{array}{l}\text { Causes a biological response allowing for tissue bonding to } \\
\text { the material; surface reactivity influences ability to bond to } \\
\text { bone; example: bioactive glass and ceramics. }\end{array}$ & Ducheyne et al., 1999 \\
\hline Allogeneic graft & $\begin{array}{l}\text { Tissue or cells obtained from donor material of same species } \\
\text { as recipient; osteoinductive and osteoconductive; can be } \\
\text { fresh or frozen. }\end{array}$ & $\begin{array}{l}\text { Roselló Llabrés et al., } \\
\qquad 2014\end{array}$ \\
\hline $\begin{array}{l}\text { Autologous } \\
\text { graft }\end{array}$ & $\begin{array}{l}\text { Tissue or cells obtained from patient receiving treatment; } \\
\text { osteoinductive and osteoconductive. }\end{array}$ & $\begin{array}{l}\text { Roselló Llabrés et al., } \\
2014\end{array}$ \\
\hline Xenogenic graft & $\begin{array}{l}\text { Tissue or cells obtained from a non-human source; example: } \\
\text { bovine, porcine. }\end{array}$ & $\begin{array}{l}\text { Roselló Llabrés et al., } \\
2014\end{array}$ \\
\hline
\end{tabular}

bone formation in EO. This can be recapitulated in TERM by differentiating MSCs chondrogenically and implanting them subcutaneously either as pellets or seeded in scaffolds (Knuth et al., 2017; Scotti et al., 2010; Tonnarelli et al., 2014; van der Stok et al., 2014). This seems to mirror developmental EO and shows excellent integration within the host tissue (Chan et al., 2009). Tissue-engineered EO, utilising MSCs, has been proven as a viable method to achieve bone formation (Dickhut et al., 2009; Hennig et al., 2007; Janicki et al., 2010; Jukes et al., 2008; Karoliina et al., 2008) (Fig. 2). Huang et al. (2006) demonstrated the ability of chondrogenically-primed MSCs, loaded into a hyaluronan/gelatine scaffold, to form bone. Bahney et al. (2014) and van der Stok et al. (2014), each independently, demonstrated how these chondrogenic MSCs could also be used to partially repair a critical-size defect even without a biomaterial support. Interestingly, this has been shown to be specific for chondrogenically-differentiated MSCs, as chondrocytes following expansion and differentiation will not form bone or bone marrow in vivo despite similar culture characteristics. Whether this is associated with the developmental origin of these cells or their expression of specific proteins, such as COLX - a hypertrophy-associated collagen not expressed by culture-expanded chondrocytes - is unknown (Hellingman et al., 2011; Pelttari et al., 2006; Pleumeekers et al., 2014). It is also possible that chondrocytes do not interact with cells of the host in a similar fashion. In order to develop better TERM approaches to bone defect repair recapitulating EO, understanding how MSC-mediated EO occurs and the kinetics of the process is necessary.

\section{The donor's role: recruitment of the host and long-term involvement}

Induction of vascular invasion, de novo formation of a marrow cavity and osteoclast activity observed in tissue-engineered constructs have demonstrated that endogenous host cells have a role in new-bone formation (Farrell et al., 2011; Tasso et al., 2009; Tasso et al., 2010; Tortelli et al., 2010). Donor MSCs directly contribute to bone-forming cell populations in TERM EO. Using cell-labelling methods, implanted chondrogenically-differentiated MSCs have been shown to persist within the bone matrix and contribute directly to bone formation (Bahney et al., 2014; Farrell et al., 2011; Scotti et al., 2013). Farrell et al. (2011) suggested that the initial bone formation is mediated by donor MSCs. Using immunocompetent transgenic rats overexpressing hPLA, donor cells were tracked following implantation into syngeneic wild type rats. A mixed population of both positive and negative hPLAP cells found embedded within the bone matrix demonstrated that cells were of both donor and host origin. Scotti et al. (2013) further suggested that donor cells that persist in the newly formed bone may have undergone trans-differentiation to osteoblast-like cells. They reported that donor and host bone have a zonal distribution. Host cells contribute to bone formation in the outer periphery of the implant and donor cells in the central portion (Scotti et al., 2013). Although Scotti et al. (2013) hypothesised that over time these donor cells would be replaced by host cells, Bahney et al. (2014) suggested that most of the bone formation is donor-derived. This research contrasts with the developmental situation where it is 
believed that following hypertrophic differentiation of chondrocytes, apoptosis is their only fate, as shown in previous avian-based research (Gibson et al., 1995). Recently, this theory has been challenged. Studies in development, fracture repair and TERM showed that hypertrophic chondrocytes do not all undergo apoptosis. Rather, a subset of them are plastic and capable of transdifferentiating into osteoblasts or osteoblast-like cells, further aiding in the process of bone formation (Bahney et al., 2014; Yang et al., 2014; Zhou et al., 2014). From a developmental point of view, Yang et al. (2014) showed that these transdifferentiated hypertrophic chondrocytes persist throughout development, being present not only in foetal bone but also in the bone of adult mice. These finds have changed how researchers view bone homeostasis in development and in TERM since chondrocytes do contribute to bone formation. In tissue engineering, there is a trend towards development of acellular grafts which are, indeed, attractive from a clinical perspective. However, knowing that implanted cells play an important role in bone formation, it may be necessary to rethink such approaches in order to maximise bone output. Certainly, in more challenging clinical situations.

\section{The role of the ECM in MSC-mediated EO}

During chondrogenic differentiation of MSCs, a bioactive matrix is produced which can greatly influence EO in vivo. Studies have suggested that the quality of the pre-implantation matrix influences in vivo bone formation. Scotti et. al (2010) reported that after longer priming, more chondrogenic induction and GAG production is achieved, resulting in better bone formation following implantation. Knuth et al. (2017) reported how stronger chondrogenic induction can influence in vivo bone formation; however, they hypothesised that a more GAGrich matrix delays bone marrow formation due to delayed remodelling. Perhaps this indicates that parameters, using ECM components produced by chondrogenically-differentiated MSCs, can be set to assess bone formation; nevertheless, performing this without destroying the pellet would be difficult. Recently, Correa et al. (2015) have suggested that chondrogenic potential can be influenced through the addition of certain FGFs which modulate TGF $\beta$ receptors, in turn altering GAG concentration. If so, researchers could utilise this approach to alter GAG production within the pre-implantation constructs. However, research in this area has yielded conflicting data and how TGF $\beta$ receptor modulation influence ECM production by MSCs is still an area of ongoing investigation (Correa et al., 2015; de Kroon et al., 2015).

When trying to further understand how the ECM influences EO, valuable insight comes also from the use of chondrogenically-differentiated MSCs, not to achieve EO but as a tissue engineering cartilage replacement. Chondrocytes formed through differentiation of MSCs as compared to native chondrocytes exhibit clear differences in structure, ECM deposition, cellular phenotypes and mechanical properties (as reviewed by Somoza et al., 2018). Researchers are investigating how they can prevent tissue-engineering MSC cartilage constructs from forming bone in vivo. For instance, suppression of canonical WNT signalling during chondrogenic differentiation results in less hypertrophic constructs, containing less COLX in the ECM, which has a negative effect on bone formation in vivo (Narcisi et

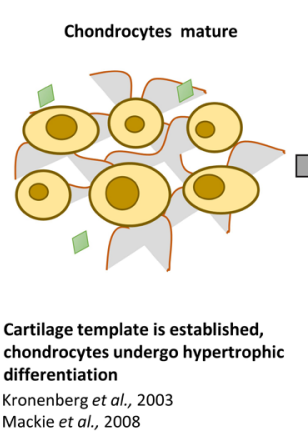

Legend

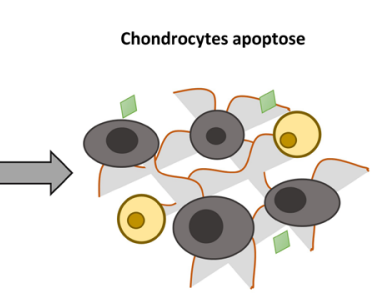

A specific subset of chondrocytes undergo apoptosis (black) leaving channels for easier vascular invasion Yang et al., 2014 Zhou et al., 2014

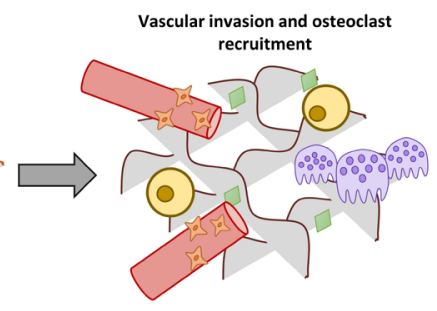

Factors released by matrix degradation and chondrocytes recruiting vasculature/preosteoblasts and osteoclasts for matrix remodellin Colnot et al., 2001 Engsig et al., 2000 Maes et al., 2010

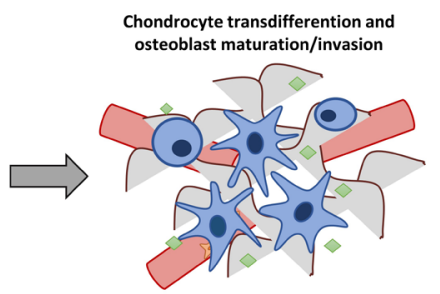

Remaining chondrocytes transdifferentiate, preosteoblast mature, and invading osteoblasts from bone collar contribute to bone formation Bahney et al., 2014 Maes et al, 2010 Zhou et al., 2014

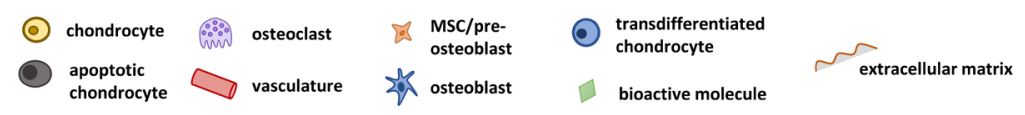

Fig. 1. Snapshot of cellular invasion and behaviour during developmental EO. Following the establishment of the cartilage template, a specific subset of hypertrophic chondrocytes undergoes apoptosis. This creates space for the nearby vasculature to invade and release bioactive molecules within the matrix. At the same time, pericytic-like pre-osteoblasts, attached to the side of the vasculature, invade it by passive migration. Factors released from the degraded ECM further aid in the recruitment of matrix-remodelling osteoclasts. The non-apoptotic chondrocytes found within the matrix are capable of trans-differentiating into osteoblastlike cells that, in combination with mature osteoblasts, contribute to bone formation. 
al., 2015). This may indicate that, for improved bone formation, the enhancement of the WNT signalling pathway during chondrogenic differentiation would have a beneficial effect on ECM and cell behaviour for bone repair. Importantly, Narcisi et al. (2015) also highlighted the importance of hypertrophic differentiation for the induction of bone formation with MSC-based endochondral grafts.

Developmentally, hypertrophic differentiation precedes mineralisation and, during this phase, $45 \%$ of the collagens produced is COLX (Luvalle et al., 1992). COLX adds to the structural stability in the surrounding pericellular network of hypertrophic chondrocytes (Schmid and Linsenmayer, 1985; Shen, 2005) but, from a bone formation stand point, its role can be more clearly seen in $\mathrm{Tg}$ and $\mathrm{KO}$ studies. In such studies, perinatal death is reported in the absence of COLX (around $25 \%$ in Tg mice and $10 \%$ in $\mathrm{KO}$ mice), with the surviving mice exhibiting a range of phenotypes including dwarfism, skeletal abnormalities, defective haematopoiesis or normal phenotype (Campbell et al., 2004; Jacenko et al., 2001; Jacenko et al., 2002; Kwan et al., 1997). The absence of COLX has an impact on the normal skeletal development in mice, but the exact mechanisms contributing to each of these abnormalities needs to be further explored to truly understand how COLX contributes to bone formation and the supportive role it plays during the process. In the absence of COLX, abnormal GAG distribution and decreased HSPG content around hypertrophic chondrocytes is reported (Jacenko et al., 2001). Proper proteoglycan distribution throughout the remodelled matrix is essential as it not only plays a role in stabilising the
ECM, but also regulates the availability of growth factors trapped within the matrix that are crucial for EO, contributing to induction of blood vessel invasion and attraction of matrix remodelling cells, such as osteoclasts, in a timely manner (Kim et al., 2011; Yang et al., 2012). Proper ECM arrangement is not only important with regards to the abovementioned aspects but also for proper placement of smaller structures, such as matrix vesicles.

Matrix vesicles are small structures that bud from the membrane of chondrocytes, osteoblasts and other cells. These structures carry with them, among other things, a collection of bioactive enzymes, proteins and phospholipids, specific to the cell they are produced from, that are important in the initiation of calcification (Anderson et al., 2005; Golub, 2009; Lohan et al., 2017). Matrix vesicles become entrapped in the ECM and help attract cells through their content (i.e. VEGF to attract blood vessels, BMPs to attract osteoblasts, etc.), making their point of anchoring and zonal distribution crucial for proper cell recruitment to the correct area (Kirsch et al., 2000; Nahar et al., 2008). Research has focussed on the interactions between COLX and annexin V, which is found on matrix vesicles. Annexin $\mathrm{V}$ facilitates calcium influx into matrix vesicles, which is important for the initiation of biomineralisation within the vesicles, in turn influencing matrix mineralisation and bone formation. COLX can selectively bind to annexin $\mathrm{V}$, initiating this influx of calcium into the matrix vesicles (Kirsch and Pfäffle, 1992; Wu et al., 1991). Others reported that when COLX is absent, vesicle distribution throughout the matrix is disrupted and subsequent bone formation is stunted (Kwan
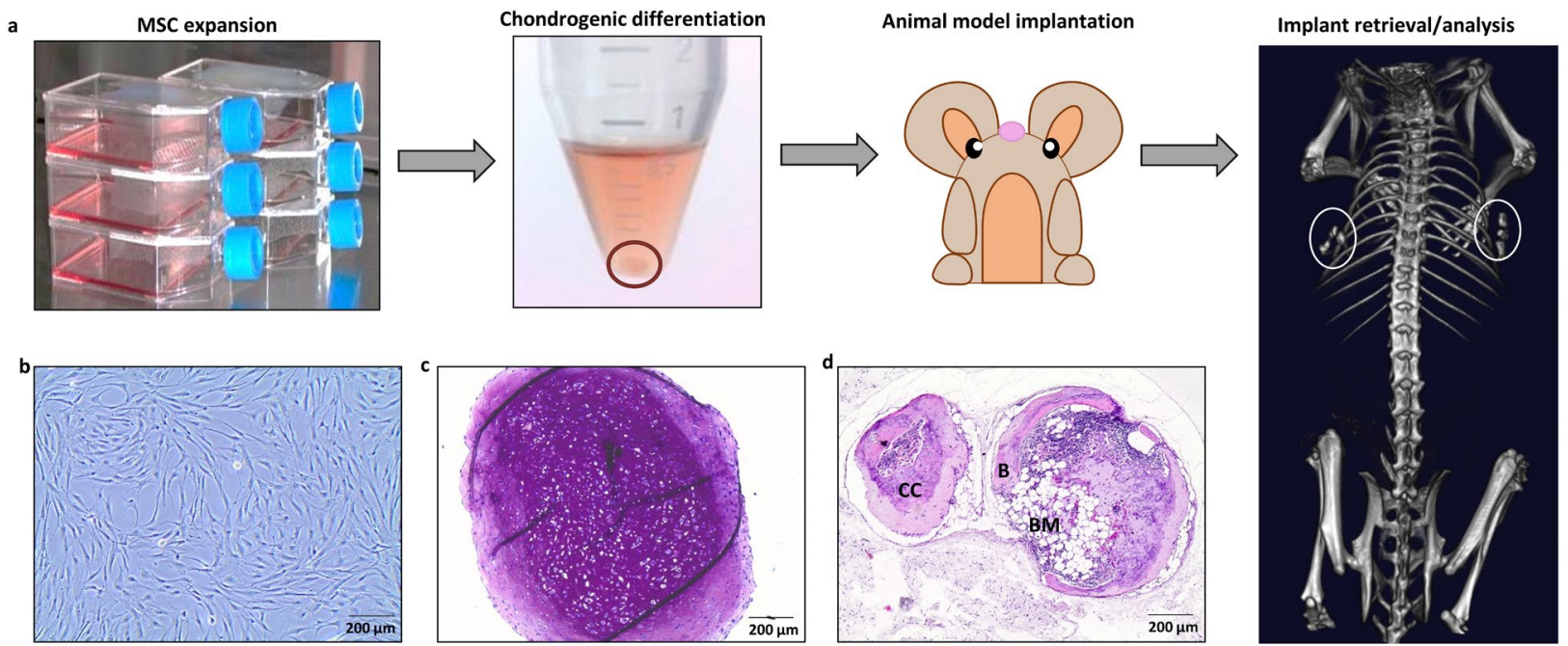

Fig. 2. Achieving tissue engineered EO. (a) MSCs are expanded to reach the required cell number through cell passage. Then, MSCs are chondrogenically-differentiated, usually through the addition of TGF $\beta$, dexamethasone and vitamin C (here a chondrogenic pellet is shown in the red circle). Following differentiation, the resulting chondrocytes are implanted in an animal model for a predetermined time. Following implantation, the resulting construct can be retrieved and analysed (constructs in white circles). (b) Representative MSCs during expansion phase. (c) A representative thionine staining of MSCs chondrogenically-differentiated for $21 \mathrm{~d}$ trough pellet culture. (d) Haemotoxylin and eosin staining showing representative bone formed from chondrogenically-differentiated MSCs after 8 weeks of subcutaneous implantation in nude mice (B-bone, CC-calcified cartilage, BM-bone marrow). 
et al., 1997; Wu et al., 1991). This is alarming and shows that proper placement of matrix vesicles is required for cell attraction to the proper site of bone formation. However, this conclusion is challenged by others in the field who found that knocking out annexin $\mathrm{V}$ results in no change in mineralisation or bone formation (Grskovic et al., 2012). Although initially these results appear to be contradictory, there could be a simple explanation. COLX plays a role in supporting and maintaining ECM proteoglycan and collagen organisation. When COLX is absent, these are no longer properly organised. Matrix vesicles also associate with the hyaluronic-acid-binding region found in proteoglycans, which can also result in calcium influx (Wu et al., 1991). If COLX is absent, matrix vesicles can possibly associate more strongly with proteoglycans, allowing them to be entrapped in the matrix, possibly no longer specifically, at the border of the chondro-osseous junction, but still able to initiate mineralisation, thus allowing bone formation to still take place.

EO also influences proper development of the bone marrow niche and proper haematopoiesis, which studies have suggested is also partially regulated by COLX. Cytokines, chemokines and growth factors bind and interact with HSPG, in part regulating or controlling an immune response (Sweeney et al., 2008; Wu et al., 1991). COLX decrease correlates with a decrease in HSPG and a dysregulation of the immune system of $\mathrm{Tg}$ mice. Additionally, an increase in factors that play a role in regulating immune responses - including IL-4, IL12, CTACK and leptin, which all bind to HSPG - and major changes to the immune system itself are shown. Mice with defective or missing COLX often have a severely decreased immune cell count. Although the immune cells that remain in the mouse often function properly, the immune response they elicit cannot be controlled, ultimately leading to death in immune- challenge studies (Sweeney et al., 2008). When mice with defective/missing COLX are challenged with an opportunistic parasite, they can initially clear the parasitic infection but do not recover and ultimately die. Post-mortem investigation shows enlarged livers and increased parasite cysts in the brain, liver and lungs, both indicative of a malfunctioned immune response (Sweeney et al., 2008). With a decreased HSPG count and an increased production of immune factors, the body is unable to regulate the response properly. Researchers have argued over the importance of COLX in regulating the immune response, as conflicting results have been shown (Kwan et al., 1997; Rosatil et al., 1994). However, the differences observed between researchers may also come down to the genetic profile of the models they used.

\section{Osteoimmunology from a tissue engineering perspective}

In large bone defects, the cells of the immune system play an important role. The complex interaction between cells of the skeletal system and the immune system is critical for successful bone repair and is initiated by an inflammatory response to the damaged tissue (Dar et al., 2018; Kolar et al., 2010; Mountziaris and Mikos, 2008; Pape et al., 2010). This leads to the secretion of pro-inflammatory cytokines, including TNF $\alpha$, IL-6 and IL-1 $\beta$ (Gerstenfeld et al., 2003; Mountziaris and Mikos, 2008). These cytokines can induce angiogenesis and attract cells of the innate immune response (monocytes, macrophages, DCs, neutrophils and NK cells). Subsequently, those cells release specific cytokines and growth factors which attract cells of the adaptive immune system ( $\mathrm{T}$ and B cells) (Kovach et al., 2015). Immune cells are not the only cells attracted during this inflammatory
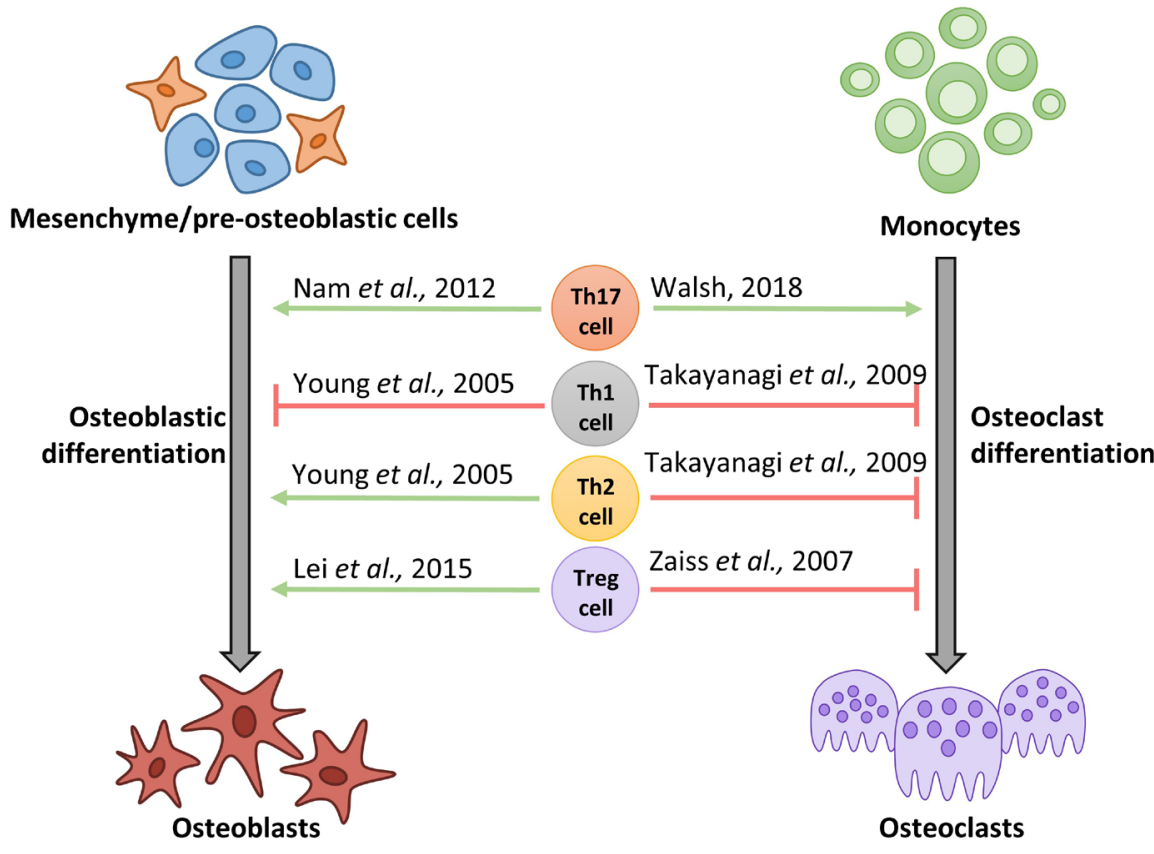

Fig. 3. T cells can influence osteoblastic and osteoclastic maturation. The release of cytokines and various growth factors during bone formation and fracture repair results in the recruitment of various immune cells which can influence bone formation and remodelling (green arrow: positive influence, red bar line: negative influence). 
response. Bone-specific growth factors such as TGF $\beta$ and BMP-2 are also secreted, leading to the recruitment of osteoprogenitor cells (including MSCs) to the site of inflammation (Kovach et al., 2015). The combined expression of growth factors with secretion of inflammatory mediators induces the proliferation and differentiation of osteoprogenitor cells to osteoblasts (Dimitriou et al., 2011; Loi et al., 2016; Mizuno et al., 1990). IMO and EO are the two processes by which osteoprogenitor cells can differentiate to osteoblasts. Unlike in IMO, during $\mathrm{EO}$, the secretion of TGF $\beta 2$ or $3, \mathrm{BMPs}$ and other signalling molecules, each of which can be influenced by immune cells, leads to the formation of a cartilage template that is replaced by woven bone (Brighton, 1984; Einhorn and Gerstenfeld, 2015; Gerstenfeld et al., 2003; Kolar et al., 2010; Kuntzman, 2010). Most fractures heal through EO and previous studies have demonstrated the importance of the immune system during the repair process; lymphocytes, in particular, are crucial for fracture healing (Schindeler et al., 2008). During bone remodelling, infiltrating $\mathrm{T}$ and $\mathrm{B}$ cells into the fracture callus are negatively involved in the bone repair process (Konnecke et al., 2014; Young et al., 2005). During bone remodelling, Th1, Th2 and regulatory T cells negatively influence osteoclast maturation; however, Th17 cells show a positive effect on osteoclast formation (Takayanagi, 2009; Walsh et al., 2018; Zaiss et al., 2007). Mice lacking $\mathrm{T}$ and $\mathrm{B}$ cells appear to have accelerated fracture healing as compared to those with a fully competent immune system (Toben et al., 2011). More specifically, CD8 T cells inhibit fracture repair (Reinke et al., 2013). However, on the other hand, other T cells have varying effects on bone formation/regeneration depending on the studied subtype (Lei et al., 2015; Nam et al., 2012; Young et al., 2005). Collectively, the complex interaction between the immune system and the cells of the skeletal system is critical for the outcome of the bone repair/regeneration as the manipulation of a specific subset of immune cells could greatly impact bone formation.

The use of autologous cells for bone regeneration is ideal due to the lack of immune rejection upon implantation. However, autologous cells have the drawback of the limited quantity of material that can be obtained. Moreover, the material that is obtained is usually of poor quality. This is due to the fact that autologous cell transplantation is generally needed in elderly and diseased patients and, therefore, having cells with poor proliferative and differentiation capacities as compared to those that could be obtained from healthy individuals (Mueller and Glowacki, 2001). Furthermore, treating patients with their own cells can cause a major delay in treatment timetables due to in vitro cell manipulations (e.g. expansion and quality control) before cells can be administered back into the patient. Taking this into consideration, new and improved TERM-based approaches to bone repair need to be developed.
The use of allogeneic cells would be preferable as there would be an immediate approved stock of cells ready to treat a patient. This advantage has led to an increased research interest aiming at using allogeneic cells for TERM applications. Research on allogeneic MSCs has demonstrated that they are somewhat immunoevasive, due to low surface expression of costimulatory molecules (e.g. CD80 and CD86) and MHC class II (Aggarwal and Pittenger, 2005; Ankrum et al., 2014; Le Blanc and Ringden, 2007; Nauta and Fibbe, 2007). Such an aspect is advantageous as MSCs will be implanted into an inflammatory environment during fracture repair (Ankrum et al., 2014; Asari et al., 2009; Corcione et al., 2006; Djouad et al., 2007; Jiang et al., 2005; Sotiropoulou et al., 2006; Spaggiari et al., 2009; Spaggiari et al., 2008; Zhao et al., 2012; Zheng et al., 2008). In normal situations, implantation of allogeneic cells would lead to cell rejection by the adaptive immune system. However, allogeneic MSCs can evade the immune response and in some instances avoid rejection upon implantation (Ankrum et al., 2014; Ryan et al., 2005). In studies focussed on the use of allogeneic MSCs for bone repair, the immune response has been shown to play an important role in the process. Bone regeneration induced by allogeneic MSCs is negatively impacted by Th1 cells through the inhibition of osteogenesis-specific gene expression (osteocalcin, Runx2 and ALP) (Dighe et al., 2013). On the other hand, osteogenesis is promoted by Th2, Th17 and regulatory T cells (Kovach et al., 2015; Liu et al., 2011; Omar et al., 2011). While there have been numerous studies on allogeneic undifferentiated MSCs, little investigation has been carried on how the immune system responds to allogeneic MSCs when they are pre-differentiated into another tissue type prior to implantation. Allogeneic undifferentiated MSCs have been shown to be non-immunogenic (Aggarwal and Pittenger, 2005; English, 2013; Gao et al., 2016; Hoogduijn et al., 2010; Nauta and Fibbe, 2007). Due to their immunoevasive nature, they can modify the immune system to their desired purpose. Few studies have investigated the effects of allogeneic chondrogenic MSCs on the immune system. Thus far, results have been conflicting, with reports demonstrating allogeneic chondrogenic MSCs to be both immunogenic (Mukonoweshuro et al., 2014; Ryan et al., 2014) and non-immunogenic (Adkisson et al., 2010; Kiernan et al., 2016; Le Blanc et al., 2003; Zheng et al., 2008).

The contradictory results were highly dependent on how the co-culturing work was performed during the experiments. Even in the in vivo setting, little is known about the effects of these pre-differentiated MSCs on the immune system. Kiernan et al. (2016) have recently detailed the various studies that have focussed on the interactions between the immune system and allogeneic differentiated MSCs in the context of bone tissue engineering. More recently, the immune-privileged nature of allogeneic MSCs has been called into question. As reviewed by Griffin 
et al. (2013) and Lohan et al. (2017), host responses vary in response to the presence of allogeneic MSCs from minor inflammation to right out rejection. The idea that allogeneic MSCs could be recognised and targeted by the host is concerning for many in the field of tissue engineering. It is clear from these studies that there is more research that needs to be conducted to determine how pre-differentiated MSCs interact with the immune system in an allogeneic setting before these cells can be used clinically. However, it appears increasingly unlikely that MSCs or differentiated MSCs are truly incapable of completely evading the immune system. The question to be answered is whether this is an issue to be concerned about.

\section{Further considerations, towards improved bone output}

MSC-mediated endochondral bone formation has yielded some promising results in animal model defect repair; however, treatment of large bone defects is still problematic. Although Harada et al. (2014) showed how chondrogenically-primed rat MSCs could heal a critical-size defect, no other group has demonstrated such large bone defect repair. Although MSC-mediated EO can form bone in vivo, the quantity usually formed, outside Harada et al. (2014) study, is insufficient to treat large bone defects. From a translational perspective, the volume of chondrogenic MSCs required to properly heal critical-size defects would require unmanageable cell numbers, incubator space, reagents and time to maintain, which would make the cost of such constructs astronomical (Penick et al., 2005; van der Stok et al., 2014). In order to treat large defects, scaleup approaches are necessary to improve bone output.

When considering scaled-up bone formation, the need for successful vascularisation to maintain cell health during regeneration must be considered. As most cells of the body are rarely more than 100$200 \mu \mathrm{m}$ away from a capillary, due to diffusion limits influencing their behaviour (Biederman-Thorson et al., 2013; Ko et al., 2007), proper vascularisation in TERM constructs is critical. Although chondrocytes are thought to be well suited to survive in the initial defect site, as their true environment is also hypoxic and avascular (Pfander and Gelse, 2007), remodelling, vessel invasion and bone formation introduce new cells with variable oxygen/nutrient requirements into the defect site (Ko et al., 2007), making vascularisation crucial to ensure these cells' survival. In small defect repair, vascularisation occurs rapidly enough to allow graft survival and integration; however, with a large defect, natural vascularisation rates may not be sufficient. Therefore, vascularisation must be induced or compensated for in the initial implanted construct to prevent cell death. Pre-vascularisation of chondrogenic grafts pre-implantation has shown more promising results ( $\mathrm{Ng}$ et al., 2017; Yousefi et al., 2016). Freeman et al. (2015) showed that the prevascularisation of chondrogenic MSCs can result in accelerated vascularisation, host cell survival and ossification versus non-vascularised counterparts. These constructs were implanted for only 4 weeks but it would be interesting to see how constructs perform following longer in vivo implantation or in immunocompetent animals. These studies are promising but special care must be taken when selecting endothelial cell sources since the phenotype of the cell differs depending on the tissue type they are isolated from (Chi et al., 2003; Garlanda and Dejana, 1997). Takigawa (2013) investigated how the addition of biologically relevant compounds known to influence endothelial cell behaviour, such as VEGF, could be utilised for improving graft vascularisation. However, high doses of VEGF result in uncontrollable bone formation, indicating further research is required to make this a more viable option (Maes et al., 2010). By accelerating processes which are known to be important for in vivo bone formation, such as vascularisation, it could be possible to, not only improve graft performance, but also increase bone formation, as bone-forming osteocytes can invade the cartilage template migrating through the vasculature (Maes, 2013; Maes et al., 2010). From a TERM approach, pre-vascularising grafts or inducing faster vascularisation is advantageous to not only tackle the issue of poor vascularisation but also to increase bone formation in the process.

Given the complications associated with cellbased approaches for tissue regeneration, there is the attempt to find possible cell-free approaches, which could circumvent these limitations. MSCs used in endochondral tissue engineering bone grafts directly contribute to the bone-forming population (Bahney et al., 2014; Farrell et al., 2011; Mendes et al., 2018; Scotti et al., 2013). Implanted chondrogenicallydifferentiated MSCs persist within the bone matrix and contribute directly to bone formation, instructing host bone formation throughout the process (Bahney et al., 2014; Farrell et al., 2011; Mendes et al., 2018; Scotti et al., 2013). These studies have suggested that implanted cells are essential for proper bone formation; however, devitalised grafts derived from chondrogenically-differentiated MSCs can also form endochondral bone in vivo (Bourgine, 2013; Bourgine et al., 2014a; Bourgine et al., 2014b; Cunniffe et al., 2015). Bourgine et al. (2013; 2014a; 2014b) created decellularised grafts which maintain bone formation potential once implanted. They utilised immortalised cell lines - eliminating many of the culture-induced issues associated with MSCs - which are decellularised through activation of an engineered death-inducible receptor within the cell. Once decellularised and implanted, these constructs show promising bone formation ability. Moreover, these immortalised cells could be further manipulated to overexpress factors known to improve bone formation, such as BMP2, which, in turn, would be 
incorporated in the ECM and could further improve bone output. Cunniffe et al. (2015), following this same line of research, showed that matrices produced specifically by hypertrophic chondrogenicallydifferentiated MSCs produced significantly more bone than non-hypertrophic matrices, indicating that something not yet identified but produced specifically during hypertrophy could be the key to improved bone formation. Although bone formed by acellular grafts produced significantly less bone volume than cellularised counterparts, these cell-free grafts are still able to recruit host vasculature and cells required for proper bone formation (Bourgine, 2013; Bourgine et al., 2014a). With further optimisation, they could be a promising alternative to current autologous bone grafts. Although decellularised grafts and off-the-shelf treatment options are an ideal solution for tissue engineering, it remains that current cell-based approaches yield better bone formation than acellular counterparts. As such, a popular scale-up approach consists of using growth factors combined with novel biomaterials. Growth factors important for developmental induction of EO, such as BMP-2 (Decambron et al., 2017; Penick et al., 2005; Stüdle et al., 2018), TGF $\beta$ (Mendes et al., 2018; Stüdle et al., 2018), VEGF (Carlevaro et al., 2000; Gerber et al., 1999), PRP (Janssen et al., 2013) as well as potentially novel factors (Fahmy-Garcia et al., 2017) are being characterised to determine if their use in combination with MSCs would improve bone output. The use of these factors has shown variable results, performing as well as, better or worse than iliac crest bone (Janssen et al., 2013). Two drawbacks associated with this approach are that these factors are extremely expensive and are used at supraphysiological levels, which is associated with additional risk. For example, high doses of BMP-2 can cause soft tissue swelling (Shahlaie and Kim, 2008), abnormal excessive bone formation (Zara et al., 2011) and increased cancer risk (Carragee et al., 2013). As such, researchers are also investigating other compounds which are known to be involved in EO and could possibly be used at more physiologically acceptable doses. This includes GDF5. This protein is well known for its role in joint formation, chondrogenesis and hypertrophic differentiation and is also a member of a subgroup of BMPs (Coleman et al., 2013). Other proteins which are more recently identified as being important during EO, including CTGF (also known as CCN2) and HMGB1, have also been investigated as possible additions to improve bone formation as they have shown positive results in vitro for improved cell recruitment, vascularisation and osteogenesis (Khattab et al., 2015; Kubota and Takigawa, 2011; Takigawa, 2013; Taniguchi et al., 2007). Such proteins could be used at more physiologically relevant doses as compared to BMP-2 (Fahmy-Garcia et al., 2017). However, even when supraphysiological doses are required, researchers are looking for ways to possibly decrease the effective dosage required to prevent these unwanted side effects. By coupling or crosslinking factors to matrices, the concentration of these compounds can be reduced to something more physiologically acceptable (Mumcuoglu et al., 2018; Quinlan et al., 2015). Further research into the identification of new biologically relevant compounds is also useful. Recent studies have identified new stem cell populations which are activated in response to acute skeletal injury (Chan et al., 2018). By studying the secreted profile of these cells in comparison with controls, new relevant targets could be identified which may not even require supraphysiological doses to be effective. Additionally, the use of organs-on-achip and other computational models, which have been proven promising to identify/validate targets and have improved screening methods (Esch et al., 2015), could accelerate results and research.

\section{Conclusions}

Modelling grafts in tissue engineering after EO has been an active area of research in bone tissue engineering for years. The initial cartilage graft is well suited to survive in an avascular environment and it can induce, on its own, the migration of all the previously mentioned cell types. Although it is a reproducible method for bone formation, progress to enhance the bone-forming capacity of these constructs, to properly fill large bone defects, is moving slowly. However, as the understanding of the interactions that take place improves - not only between donor and host cells but also those of a fully functioning immune system - a better appreciation of how to improve such grafts will follow. As research in the field continues, graft vascularisation, integration and bone output will improve, making these tissueengineered endochondral grafts a viable alternative to autologous bone graft substitutes in the future.

\section{References}

Adkisson HDt, Martin JA, Amendola RL, Milliman C, Mauch KA, Katwal AB, Seyedin M, Amendola A, Streeter PR, Buckwalter JA (2010) The potential of human allogeneic juvenile chondrocytes for restoration of articular cartilage. Am J Sports Med 38: 1324-1333.

Aggarwal S, Pittenger MF (2005) Human mesenchymal stem cells modulate allogeneic immune cell responses. Blood 105: 1815-1822.

Anderson HC, Garimella R, Tague SE (2005) The role of matrix vesicles in growth plate development and biomineralization. Front Biosci 10: 822-837.

Ankrum JA, Ong JF, Karp JM (2014) Mesenchymal stem cells: immune evasive, not immune privileged. Nature Biotechnol 32: 252-260.

Asari S, Itakura S, Ferreri K, Liu CP, Kuroda Y, Kandeel F, Mullen Y (2009) Mesenchymal stem cells 
suppress B-cell terminal differentiation. Exp Hematol 37: 604-615.

Bahney CS, Hu DP, Taylor AJ, Ferro F, Britz HM, Hallgrimsson B, Johnstone B, Miclau T, Marcucio RS (2014) Stem cell-derived endochondral cartilage stimulates bone healing by tissue transformation. J Bone Miner Res 29: 1269-1282.

Ballock RT, O'Keefe RJ (2003) The biology of the growth plate. JBJS 85: 715-726.

Bauer TW, Muschler GF (2000) Bone graft materials: an overview of the basic science. Clin Orthop Relat Res 371: 10-27.

Biederman-Thorson MA (2013) Human physiology. Editors: Schmidt RF, Thews G. SpringerVerlag.

Bourgine P (2013) Combination of cell immortalization and apoptosis induction to engineer decellularized matrices as bone graft materials. University of Basel. DOI: 10.5451/unibas-006222300.

Bourgine P, Le Magnen C, Pigeot S, Geurts J, Scherberich A, Martin I (2014a) Combination of immortalization and inducible death strategies to generate a human mesenchymal stromal cell line with controlled survival. Stem Cell Res 12: 584-598.

Bourgine PE, Scotti C, Pigeot S, Tchang LA, Todorov A, Martin I (2014b) Osteoinductivity of engineered cartilaginous templates devitalized by inducible apoptosis. Proc Natl Acad Sci U S A 111: 17426-17431.

Brighton CT (1984) The biology of fracture repair. Instr Course Lect 33: 60-82.

Campbell MR, Gress CJ, Appleman EH, Jacenko $\mathrm{O}$ (2004) Chicken collagen $X$ regulatory sequences restrict transgene expression to hypertrophic cartilage in mice. Am J Pathol 164: 487-499.

Carlevaro MF, Cermelli S, Cancedda R, Cancedda FD (2000) Vascular endothelial growth factor (VEGF) in cartilage neovascularization and chondrocyte differentiation: auto-paracrine role during endochondral bone formation. J Cell Sci 113: 59-69.

Carragee EJ, Chu G, Rohatgi R, Hurwitz EL, Weiner BK, Yoon ST, Comer G, Kopjar B (2013) Cancer risk after use of recombinant bone morphogenetic protein-2 for spinal arthrodesis. JBJS 95: 1537-1545.

Cervantes-Diaz F, Contreras P, Marcellini S (2017) Evolutionary origin of endochondral ossification: the transdifferentiation hypothesis. Dev Genes Evol 227: 121-127.

Chan CK, Chen CC, Luppen CA, Kim JB, DeBoer AT, Wei K, Helms JA, Kuo CJ, Kraft DL, Weissman IL (2009) Endochondral ossification is required for haematopoietic stem-cell niche formation. Nature 457: 490-494.

Chan CK, Gulati GS, Sinha R, Tompkins JV, Lopez M, Carter AC, Ransom RC, Reinisch A, Wearda T, Murphy M (2018) Identification of the human skeletal stem cell. Cell 175: 43-56.

Chatterjea A, Meijer G, van Blitterswijk C, de Boer J (2010) Clinical application of human mesenchymal stromal cells for bone tissue engineering. Stem Cells Int 2010: 215625. DOI: 10.4061/2010/215625.

Chi J-T, Chang HY, Haraldsen G, Jahnsen FL, Troyanskaya OG, Chang DS, Wang Z, Rockson SG, van de Rijn M, Botstein D (2003) Endothelial cell diversity revealed by global expression profiling. Proc Natl Acad Sci U S A 100: 10623-10628.

Coleman CM, Vaughan EE, Browe DC, Mooney E, Howard L, Barry F (2013) Growth differentiation factor-5 enhances in vitro mesenchymal stromal cell chondrogenesis and hypertrophy. Stem Cells Dev 22: 1968-1976.

Colnot CI, Helms JA (2001) A molecular analysis of matrix remodeling and angiogenesis during long bone development. Mech Dev 100: 245-250.

Corcione A, Benvenuto F, Ferretti E, Giunti D, Cappiello V, Cazzanti F, Risso M, Gualandi F, Mancardi GL, Pistoia V, Uccelli A (2006) Human mesenchymal stem cells modulate B-cell functions. Blood 107: 367-372.

Correa D, Somoza RA, Lin P, Greenberg S, Rom E, Duesler L, Welter JF, Yayon A, Caplan AI (2015) Sequential exposure to fibroblast growth factors (FGF) 2, 9 and 18 enhances hMSC chondrogenic differentiation. Osteoarthritis Cartilage 23: 443-453.

Cunniffe GM, Vinardell T, Murphy JM, Thompson EM, Matsiko A, O'Brien FJ, Kelly DJ (2015) Porous decellularized tissue engineered hypertrophic cartilage as a scaffold for large bone defect healing. Acta Biomater 23: 82-90.

de Kroon LM, Narcisi R, Davidson ENB, Cleary MA, van Beuningen HM, Koevoet WJ, van Osch GJ, van der Kraan PM (2015) Activin receptor-like kinase receptors ALK5 and ALK1 are both required for TGF $\beta$-induced chondrogenic differentiation of human bone marrow-derived mesenchymal stem cells. PloS One 10: e0146124. DOI: 10.1371/journal. pone.0146124.

Decambron A, Fournet A, Bensidhoum M, Manassero M, Sailhan F, Petite H, LogeartAvramoglou D, Viateau V (2017) Low-dose BMP-2 and MSC dual delivery onto coral scaffold for criticalsize bone defect regeneration in sheep. J Orthop Res 35: 2637-2645.

Dickhut A, Pelttari K, Janicki P, Wagner W, Eckstein V, Egermann M, Richter W (2009) Calcification or dedifferentiation: requirement to lock mesenchymal stem cells in a desired differentiation stage. J Cell Physiol 219: 219-226.

Dighe AS, Yang S, Madhu V, Balian G, Cui Q (2013) Interferon gamma and $\mathrm{T}$ cells inhibit osteogenesis induced by allogeneic mesenchymal stromal cells. J Orthop Res 31: 227-234.

Dimitriou R, Jones E, McGonagle D, Giannoudis PV (2011) Bone regeneration: current concepts and future directions. BMC Med 9: 66. DOI: 10.1186/17417015-9-66.

Djouad F, Charbonnier LM, Bouffi C, LouisPlence P, Bony C, Apparailly F, Cantos C, Jorgensen C, Noel D (2007) Mesenchymal stem cells inhibit 
the differentiation of dendritic cells through an interleukin-6-dependent mechanism. Stem Cells 25: 2025-2032.

Ducheyne P, Qiu Q (1999) Bioactive ceramics: the effect of surface reactivity on bone formation and bone cell function. Biomaterials 20: 2287-2303.

Einhorn TA, Gerstenfeld LC (2015) Fracture healing: mechanisms and interventions. Nat Rev Rheumatol 11: 45-54.

English K (2013) Mechanisms of mesenchymal stromal cell immunomodulation. Immunol Cell Biol 91: 19-26.

Engsig MT, Chen Q-J, Vu TH, Pedersen A-C, Therkidsen B, Lund LR, Henriksen K, Lenhard T, Foged NT, Werb Z (2000) Matrix metalloproteinase 9 and vascular endothelial growth factor are essential for osteoclast recruitment into developing long bones. J Cell Biol 151: 879-890.

Esch EW, Bahinski A, Huh D (2015) Organs-onchips at the frontiers of drug discovery. Nat Rev Drug Discov 14: 248-260.

Fahmy-Garcia S, van Driel M, Witte-Buoma J, Walles H, van Leeuwen J, van Osch G, Farrell E (2017) NELL-1, HMGB1, and CCN2 enhance migration and vasculogenesis, but not osteogenic differentiation compared to BMP2. Tissue Eng Part A 24: 207-218.

Farrell E, Both SK, Odörfer KI, Koevoet W, Kops N, O'Brien FJ, de Jong RJB, Verhaar JA, Cuijpers $\mathrm{V}$, Jansen J (2011) In-vivo generation of bone via endochondral ossification by in-vitro chondrogenic priming of adult human and rat mesenchymal stem cells. BMC musculoskeletal disorders 12: 31. DOI: 10.1186/1471-2474-12-31.

Finkemeier CG (2002) Bone-grafting and bonegraft substitutes. JBJS 84: 454-464.

Freeman FE, Allen AB, Stevens HY, Guldberg RE, McNamara LM (2015) Effects of in vitro endochondral priming and pre-vascularisation of human MSC cellular aggregates in vivo. Stem Cell Res Ther 6: 218. DOI: 10.1186/s13287-015-0210-2.

Frohlich M, Grayson WL, Wan LQ, Marolt D, Drobnic M, Vunjak-Novakovic G (2008) Tissue engineered bone grafts: biological requirements, tissue culture and clinical relevance. Curr Stem Cell Res Ther 3: 254-264.

Gao F, Chiu SM, Motan DA, Zhang Z, Chen L, Ji HL, Tse HF, Fu QL, Lian Q (2016) Mesenchymal stem cells and immunomodulation: current status and future prospects. Cell Death Dis 7: e2062. DOI: 10.1038/cddis.2015.327.

Garlanda C, Dejana E (1997) Heterogeneity of endothelial cells: specific markers. Arteriosclerosis, thrombosis, and vascular biology 17: 1193-1202.

Gawlitta D, Farrell E, Malda J, Creemers LB, Alblas J, Dhert WJ (2010) Modulating endochondral ossification of multipotent stromal cells for bone regeneration. Tissue Eng Part B Rev 16: 385-395.

Gerber H-P, Vu TH, Ryan AM, Kowalski J, Werb Z, Ferrara N (1999) VEGF couples hypertrophic cartilage remodeling, ossification and angiogenesis during endochondral bone formation. Nat Med 5: 623-628.
Gerstenfeld LC, Cullinane DM, Barnes GL, Graves DT, Einhorn TA (2003) Fracture healing as a postnatal developmental process: molecular, spatial, and temporal aspects of its regulation. J Cell Biochem 88: 873-884.

Gibson GJ, Kohler WJ, Schaffler MB (1995) Chondrocyte apoptosis in endochondral ossification of chick sterna. Dev Dyn 203: 468-476.

Golub EE (2009) Role of matrix vesicles in biomineralization. Biochimica et Biophysica Acta (BBA)-General Subjects 1790: 1592-1598.

Gómez-Barrena E, Rosset P, Lozano D, Stanovici J, Ermthaller C, Gerbhard F (2015) Bone fracture healing: Cell therapy in delayed unions and nonunions. Bone 70: 93-101.

Grskovic I, Kutsch A, Frie C, Groma G, Stermann J, Schlötzer-Schrehardt U, Niehoff A, Moss SE, Rosenbaum S, Pöschl E (2012) Depletion of annexin A5, annexin A6, and collagen $X$ causes no gross changes in matrix vesicle-mediated mineralization, but lack of collagen $X$ affects hematopoiesis and the Th1/Th2 response. J Bone Miner Res 27: 2399-2412.

Harada N, Watanabe Y, Sato K, Abe S, Yamanaka K, Sakai Y, Kaneko T, Matsushita T (2014) Bone regeneration in a massive rat femur defect through endochondral ossification achieved with chondrogenically differentiated MSCs in a degradable scaffold. Biomaterials 35: 7800-7810.

Hayden RE, Mullin DP, Patel AK (2012) Reconstruction of the segmental mandibular defect: current state of the art. Curr Opin Otolaryngol Head Neck Surg 20: 231-236.

Hellingman CA, Verwiel ET, Slagt I, Koevoet W, Poublon RM, Nolst-Trenite GJ, Baatenburg de Jong RJ, Jahr H, van Osch GJ (2011) Differences in cartilageforming capacity of expanded human chondrocytes from ear and nose and their gene expression profiles. Cell Transplant 20: 925-940.

Hennig T, Lorenz H, Thiel A, Goetzke K, Dickhut A, Geiger F, Richter W (2007) Reduced chondrogenic potential of adipose tissue derived stromal cells correlates with an altered TGFbeta receptor and BMP profile and is overcome by BMP-6. J Cell Physiol 211: 682-691.

Hoogduijn MJ, Popp F, Verbeek R, Masoodi M, Nicolaou A, Baan C, Dahlke MH (2010) The immunomodulatory properties of mesenchymal stem cells and their use for immunotherapy. Int Immunopharmacol 10: 1496-1500.

Huang JI, Durbhakula MM, Angele P, Johnstone B, Yoo JU (2006) Lunate arthroplasty with autologous mesenchymal stem cells in a rabbit model. JBJS 88: 744-752.

Jacenko O, Chan D, Franklin A, Ito S, Underhill CB, Bateman JF, Campbell MR (2001) A dominant interference collagen $x$ mutation disrupts hypertrophic chondrocyte pericellular matrix and glycosaminoglycan and proteoglycan distribution in transgenic mice. Am J Pathol 159: 2257-2269.

Jacenko O, Roberts DW, Campbell MR, McManus PM, Gress CJ, Tao Z (2002) Linking hematopoiesis 
to endochondral skeletogenesis through analysis of mice transgenic for collagen X. Am J Pathol 160: 2019-2034.

Janicki P, Kasten P, Kleinschmidt K, Luginbuehl R, Richter W (2010) Chondrogenic pre-induction of human mesenchymal stem cells on beta-TCP: enhanced bone quality by endochondral heterotopic bone formation. Acta Biomater 6: 3292-3301.

Janssen NG, Weijs WL, Koole R, Rosenberg AJ, Meijer GJ (2013) Tissue engineering strategies for alveolar cleft reconstruction: a systematic review of the literature. Clin Oral Investig 18: 219-226.

Jiang XX, Zhang Y, Liu B, Zhang SX, Wu Y, Yu XD, Mao N (2005) Human mesenchymal stem cells inhibit differentiation and function of monocyte-derived dendritic cells. Blood 105: 4120-4126.

Jukes JM, Both SK, Leusink A, Sterk LM, van Blitterswijk CA, de Boer J (2008) Endochondral bone tissue engineering using embryonic stem cells. Proc Natl Acad Sci U S A 105: 6840-6845.

Karoliina P, Eric S, Wiltrud R (2008) The use of mesenchymal stem cells for chondrogenesis. Injury 39 Suppl 1: S58-65.

Khattab HM, Aoyama E, Kubota S, Takigawa M (2015) Physical interaction of CCN2 with diverse growth factors involved in chondrocyte differentiation during endochondral ossification. J Cell Commun Signal 9: 247-254.

Kiernan CH, Hoogduijn MJ, Franquesa M, Wolvius EB, Brama PA, Farrell E (2016) Allogeneic chondrogenically differentiated human mesenchymal stromal cells do not induce immunogenic responses from T lymphocytes in vitro. Cytotherapy 18: 957-969.

Kim S-H, Turnbull J, Guimond S (2011) Extracellular matrix and cell signalling: the dynamic cooperation of integrin, proteoglycan and growth factor receptor. J Endocrinol 209: 139-151.

Kirsch T, Harrison G, Golub EE, Nah H-D (2000) The roles of annexins and types II and $X$ collagen in matrix vesicle-mediated mineralization of growth plate cartilage. J Biol Chem 275: 35577-35583.

Kirsch T, Pfäffle M (1992) Selective binding of anchorin CII (annexin V) to type II and X collagen and to chondrocalcin (C-propeptide of type II collagen) Implications for anchoring function between matrix vesicles and matrix proteins. FEBS letters 310: 143147.

Knuth C, Witte-Bouma J, Ridwan Y, Wolvius E, Farrell E (2017) Mesenchymal stem cell-mediated endochondral ossification utilising micropellets and brief chondrogenic priming. Eur Cell Mater 34: 142161.

Ko H, Milthorpe BK, McFarland CD (2007) Engineering thick tissues-the vascularisation problem. Eur Cell Mater 14: 1-19.

Kolar P, Schmidt-Bleek K, Schell H, Gaber T, Toben D, Schmidmaier G, Perka C, Buttgereit F, Duda GN (2010) The early fracture hematoma and its potential role in fracture healing. Tissue Eng Part B Rev 16: 427-434.
Konnecke I, Serra A, El Khassawna T, Schlundt C, Schell H, Hauser A, Ellinghaus A, Volk HD, Radbruch A, Duda GN, Schmidt-Bleek K (2014) T and B cells participate in bone repair by infiltrating the fracture callus in a two-wave fashion. Bone 64: 155-165.

Kovach TK, Dighe AS, Lobo PI, Cui Q (2015) Interactions between MSCs and immune cells: implications for bone healing. J Immunol Res 2015: 752510. DOI: 10.1155/2015/752510.

Kronenberg HM (2003) Developmental regulation of the growth plate. Nature 423: 332-336.

Kubota S, Takigawa M (2011) The role of CCN2 in cartilage and bone development. J Cell Commun Signal 5: 209-217.

Kuntzman A, Tortora GJ (2010) The process of fracture repair. In: Anatomy and physiology for manual therapies. John Wiley and Sons Ltd, Chichester, UK.

Kwan KM, Pang MK, Zhou S, Cowan SK, Kong RY, Pfordte T, Olsen BR, Sillence DO, Tam PP, Cheah KS (1997) Abnormal compartmentalization of cartilage matrix components in mice lacking collagen $\mathrm{X}$ : implications for function. J Cell Biol 136: 459-471.

Le Blanc K, Ringden O (2007) Immunomodulation by mesenchymal stem cells and clinical experience. J Intern Med 262: 509-525.

Le Blanc K, Tammik C, Rosendahl K, Zetterberg E, Ringden O (2003) HLA expression and immunologic properties of differentiated and undifferentiated mesenchymal stem cells. Exp Hematol 31: 890-896.

Lee JH (2016) Development of osteoconductive and osteoinductive bone healing materials. Bone Abstract 5: SS4.3. DOI: 10.1530/boneabs.5.S4.3.

LeGeros RZ (2008) Calcium phosphate-based osteoinductive materials. Chem Rev 108: 4742-4753.

Lei H, Schmidt-Bleek K, Dienelt A, Reinke P, Volk H-D (2015) Regulatory T cell-mediated antiinflammatory effects promote successful tissue repair in both indirect and direct manners. Front Pharmacol 6: 184. DOI: 10.3389/fphar.2015.00184.

Lieberman JR, Friedlaender GE (2005) Bone regeneration and repair. Biology and clinical applications. pp: 1-398. Springer. DOI: 10.1385/1592598633.

Liu Y, Wang L, Kikuiri T, Akiyama K, Chen C, Xu X, Yang R, Chen W, Wang S, Shi S (2011) Mesenchymal stem cell-based tissue regeneration is governed by recipient T lymphocytes via IFN-gamma and TNF-alpha. Nat Med 17: 1594-1601.

Loi F, Cordova LA, Pajarinen J, Lin TH, Yao Z, Goodman SB (2016) Inflammation, fracture and bone repair. Bone 86: 119-130.

Luvalle P, Daniels K, Hay ED, Olsen BR (1992) Type $X$ collagen is transcriptionally activated and specifically localized during sternal cartilage maturation. Matrix 12: 404-413.

Mackie EJ, Ahmed YA, Tatarczuch L, Chen KS, Mirams M (2008) Endochondral ossification: how cartilage is converted into bone in the developing skeleton. Int J Biochem Cell Biol 40: 46-62. 
Maes C (2013) Role and regulation of vascularization processes in endochondral bones. Calcif Tissue Int 92: 307-323.

Maes C, Goossens S, Bartunkova S, Drogat B, Coenegrachts L, Stockmans I, Moermans K, Nyabi O, Haigh K, Naessens M (2010) Increased skeletal VEGF enhances $\beta$-catenin activity and results in excessively ossified bones. EMBO J 29: 424-441.

Medici D, Olsen BR (2012) The role of endothelialmesenchymal transition in heterotopic ossification. J Bone Miner Res 27: 1619-1622.

Meijer GJ, de Bruijn JD, Koole R, van Blitterswijk CA (2008) Cell based bone tissue engineering in jaw defects. Biomaterials 29: 3053-3061.

Mendes L, Katagiri H, Tam W, Chai Y, Geris L, Roberts S, Luyten F (2018) Advancing osteochondral tissue engineering: bone morphogenetic protein, transforming growth factor, and fibroblast growth factor signaling drive ordered differentiation of periosteal cells resulting in stable cartilage and bone formation in vivo. Stem Cell Res Ther 9: 42. DOI: 10.1186/s13287-018-0787-3.

Mizuno K, Mineo K, Tachibana T, Sumi M, Matsubara T, Hirohata K (1990) The osteogenetic potential of fracture haematoma. Subperiosteal and intramuscular transplantation of the haematoma. J Bone Joint Surg Br 72: 822-829.

Mountziaris PM, Mikos AG (2008) Modulation of the inflammatory response for enhanced bone tissue regeneration. Tissue Eng Part B Rev 14: 179-186.

Mueller SM, Glowacki J (2001) Age-related decline in the osteogenic potential of human bone marrow cells cultured in three-dimensional collagen sponges. J Cell Biochem 82: 583-590.

Mukonoweshuro B, Brown CJ, Fisher J, Ingham E (2014) Immunogenicity of undifferentiated and differentiated allogeneic mouse mesenchymal stem cells. J Tissue Eng 5: 2041731414534255. DOI: 10.1177/2041731414534255.

Mumcuoglu D, Fahmy-Garcia S, Ridwan Y, Nicke J, Farrell E, Kluijtmans SG, van Osch GJ (2018) Injectable BMP-2 delivery system based on collagenderived microspheres and alginate induced bone formation in a time- and dose-dependent manner. Eur Cell Mater 35: 242-254.

Nahar NN, Missana LR, Garimella R, Tague SE, Anderson HC (2008) Matrix vesicles are carriers of bone morphogenetic proteins (BMPs), vascular endothelial growth factor (VEGF), and noncollagenous matrix proteins. J Bone Miner Metab 26: 514-519.

Nam D, Mau E, Wang Y, Wright D, Silkstone D, Whetstone H, Whyne C, Alman B (2012) T-lymphocytes enable osteoblast maturation via IL$17 \mathrm{~F}$ during the early phase of fracture repair. PloS One 7: e40044. DOI: 10.1371/journal.pone.0040044.

Narcisi R, Cleary MA, Brama PA, Hoogduijn MJ, Tüysüz N, ten Berge D, van Osch GJ (2015) Long-term expansion, enhanced chondrogenic potential, and suppression of endochondral ossification of adult human MSCs via WNT signaling modulation. Stem Cell Reports 4: 459-472.

Nauta AJ, Fibbe WE (2007) Immunomodulatory properties of mesenchymal stromal cells. Blood 110: 3499-3506.

Ng J, Spiller K, Bernhard J, Vunjak-Novakovic G (2017) Engineering vascular niche for bone tissue regeneration. In: Biology and engineering of stem cell niches. pp: 517-529. Elsevier.

Nishimura T (2015) Role of extracellular matrix in development of skeletal muscle and postmortem aging of meat. Meat Science 109: 48-55.

Omar OM, Graneli C, Ekstrom K, Karlsson C, Johansson A, Lausmaa J, Wexell CL, Thomsen P (2011) The stimulation of an osteogenic response by classical monocyte activation. Biomaterials 32: 81908204.

Pape HC, Marcucio R, Humphrey C, Colnot C, Knobe M, Harvey EJ (2010) Trauma-induced inflammation and fracture healing. J Orthop Trauma 24: 522-525.

Pelttari K, Winter A, Steck E, Goetzke K, Hennig T, Ochs BG, Aigner T, Richter W (2006) Premature induction of hypertrophy during in vitro chondrogenesis of human mesenchymal stem cells correlates with calcification and vascular invasion after ectopic transplantation in SCID mice. Arthritis Rheum 54: 3254-3266.

Penick KJ, Solchaga LA, Welter JF (2005) Highthroughput aggregate culture system to assess the chondrogenic potential of mesenchymal stem cells. Biotechniques 39: 687-691.

Petite H, Viateau V, Bensaid W, Meunier A, de Pollak C, Bourguignon M, Oudina K, Sedel L, Guillemin G (2000) Tissue-engineered bone regeneration. Nat Biotechnol 18: 959-963.

Pfander D, Gelse K (2007) Hypoxia and osteoarthritis: how chondrocytes survive hypoxic environments. Current opinion in rheumatology 19: 457-462.

Pleumeekers MM, Nimeskern L, Koevoet WL, Kops N, Poublon RM, Stok KS, van Osch GJ (2014) The in vitro and in vivo capacity of culture-expanded human cells from several sources encapsulated in alginate to form cartilage. Eur Cell Mater 27: 264-280.

Quinlan E, Thompson EM, Matsiko A, O'brien FJ, López-Noriega A (2015) Long-term controlled delivery of rhBMP-2 from collagen-hydroxyapatite scaffolds for superior bone tissue regeneration. J Control Release 207: 112-119.

Reinke S, Geissler S, Taylor WR, Schmidt-Bleek K, Juelke K, Schwachmeyer V, Dahne M, Hartwig T, Akyuz L, Meisel C, Unterwalder N, Singh NB, Reinke P, Haas NP, Volk HD, Duda GN (2013) Terminally differentiated CD8(+) T cells negatively affect bone regeneration in humans. Sci Transl Med 5: 177ra136. DOI: 10.1126/scitranslmed.3004754.

Rosatil R, Horanl GS, Piner03 GI, Garofalo S, Keene DR (1994) Normal long bone growth and development in type X collagen. Nat Genet 8: 129-135. 
Roselló Llabrés X, Roselló Camps À, Jané Salas E, Alburquerque R, Velasco Ortega E, López López J (2014) Graft materials in oral surgery: revision. In: Biomimetics, Biomaterials and Tissue Engineering. Omics Publishing Group. 19, pp 1-7.

Ryan AE, Lohan P, O'Flynn L, Treacy O, Chen X, Coleman C, Shaw G, Murphy M, Barry F, Griffin MD, Ritter T (2014) Chondrogenic differentiation increases antidonor immune response to allogeneic mesenchymal stem cell transplantation. Mol Ther 22: 655-667.

Ryan JM, Barry FP, Murphy JM, Mahon BP (2005). Mesenchymal stem cells avoid allogeneic rejection. J Inflamm (Lond) 2: 8. DOI: 10.1186/1476-9255-2-8.

Schindeler A, McDonald MM, Bokko P, Little DG (2008) Bone remodeling during fracture repair: the cellular picture. Semin Cell Dev Biol 19: 459-466.

Schmid TM, Linsenmayer TF (1985) Immunohistochemical localization of short chain cartilage collagen (type X) in avian tissues. J Cell Biol 100: 598-605.

Schrier L, Ferns SP, Barnes KM, Emons JA, Newman EI, Nilsson O, Baron J (2006) Depletion of resting zone chondrocytes during growth plate senescence. Journal of Endocrinology 189: 27-36.

Scotti C, Piccinini E, Takizawa H, Todorov A, Bourgine P, Papadimitropoulos A, Barbero A, Manz MG, Martin I (2013) Engineering of a functional bone organ through endochondral ossification. Proc Natl Acad Sci U S A 110: 3997-4002.

Scotti C, Tonnarelli B, Papadimitropoulos A, Scherberich A, Schaeren S, Schauerte A, Lopez-Rios J, Zeller R, Barbero A, Martin I (2010) Recapitulation of endochondral bone formation using human adult mesenchymal stem cells as a paradigm for developmental engineering. Proc Natl Acad Sci U S A 107: 7251-7256.

Shahlaie K, Kim KD (2008) Occipitocervical fusion using recombinant human bone morphogenetic protein-2: adverse effects due to tissue swelling and seroma. Spine 33: 2361-2366.

Shapiro F (2008) Bone development and its relation to fracture repair. The role of mesenchymal osteoblasts and surface osteoblasts. Eur Cell Mater 15: 53-76.

Shen G (2005) The role of type X collagen in facilitating and regulating endochondral ossification of articular cartilage. Orthod Craniofac Res 8: 11-17.

Sotiropoulou PA, Perez SA, Gritzapis AD, Baxevanis CN, Papamichail M (2006) Interactions between human mesenchymal stem cells and natural killer cells. Stem Cells 24: 74-85.

Spaggiari GM, Abdelrazik H, Becchetti F, Moretta L (2009) MSCs inhibit monocyte-derived DC maturation and function by selectively interfering with the generation of immature DCs: central role of MSC-derived prostaglandin E2. Blood 113: 6576-6583.

Spaggiari GM, Capobianco A, Abdelrazik H, Becchetti F, Mingari MC, Moretta L (2008) Mesenchymal stem cells inhibit natural killer- cell proliferation, cytotoxicity, and cytokine production: role of indoleamine 2,3-dioxygenase and prostaglandin E2. Blood 111: 1327-1333.

Stüdle C, Martin QV, Haumer A, Guerrero J, Centola M, Mehrkens A, Schaefer DJ, Ehrbar M, Barbero A, Martin I (2018) Spatially confined induction of endochondral ossification by functionalized hydrogels for ectopic engineering of osteochondral tissues. Biomaterials 171: 219-229.

Sweeney E, Campbell M, Watkins K, Hunter CA, Jacenko O (2008) Altered endochondral ossification in collagen $X$ mouse models leads to impaired immune responses. Dev Dyn 237: 2693-2704.

Takayanagi H (2009) Osteoimmunology and the effects of the immune system on bone. Nat Rev Rheumatol 5: 667-676.

Takigawa M (2013) CCN2: a master regulator of the genesis of bone and cartilage. J Cell Commun Signal 7: 191-201.

Taniguchi N, Yoshida K, Ito T, Tsuda M, Mishima Y, Furumatsu T, Ronfani L, Abeyama K, Kawahara K-i, Komiya S, Maruyama I, Lotz M, Bianchi ME, Asahara H (2007) Stage-specific secretion of HMGB1 in cartilage regulates endochondral ossification. Mol Cell Biol 27: 5650-5663.

Tasso R, Augello A, Boccardo S, Salvi S, Carida M, Postiglione F, Fais F, Truini M, Cancedda R, Pennesi G (2009) Recruitment of a host's osteoprogenitor cells using exogenous mesenchymal stem cells seeded on porous ceramic. Tissue Eng Part A 15: 2203-2212.

Tasso R, Fais F, Reverberi D, Tortelli F, Cancedda $R$ (2010) The recruitment of two consecutive and different waves of host stem/progenitor cells during the development of tissue-engineered bone in a murine model. Biomaterials 31: 2121-2129.

Thompson EM, Matsiko A, Farrell E, Kelly DJ, O'Brien FJ (2015) Recapitulating endochondral ossification: a promising route to in vivo bone regeneration. J Tissue Eng Regen Med 9: 889-902.

Thompson Z, Miclau T, Hu D, Helms JA (2002) A model for intramembranous ossification during fracture healing. J Orthop Res 20: 1091-1098.

Toben D, Schroeder I, El Khassawna T, Mehta M, Hoffmann JE, Frisch JT, Schell H, Lienau J, Serra A, Radbruch A, Duda GN (2011) Fracture healing is accelerated in the absence of the adaptive immune system. J Bone Miner Res 26: 113-124.

Tonnarelli B, Centola M, Barbero A, Zeller R, Martin I (2014) Re-engineering development to instruct tissue regeneration. Curr Top Dev Biol 108: 319-338.

Tortelli F, Tasso R, Loiacono F, Cancedda R (2010) The development of tissue-engineered bone of different origin through endochondral and intramembranous ossification following the implantation of mesenchymal stem cells and osteoblasts in a murine model. Biomaterials 31: 242249.

van der Stok J, Koolen M, Jahr H, Kops N, Waarsing J, Weinans H, Van der Jagt O (2014) Chondrogenically 
differentiated mesenchymal stromal cell pellets stimulate endochondral bone regeneration in criticalsized bone defects. Eur Cell Mater 27: 137-148.

Walsh MC, Takegahara N, Kim H, Choi Y (2018) Updating osteoimmunology: regulation of bone cells by innate and adaptive immunity. Nat Rev Rheumatol 14: 146-156.

Wu L, Genge B, Lloyd G, Wuthier R (1991) Collagen-binding proteins in collagenase-released matrix vesicles from cartilage. Interaction between matrix vesicle proteins and different types of collagen. J Biol Chem 266: 1195-1203.

Yang L, Tsang KY, Tang HC, Chan D, Cheah KSE (2014) Hypertrophic chondrocytes can become osteoblasts and osteocytes in endochondral bone formation. Proc Natl Acad Sci U S A 111: 12097-12102.

Yang Y, Topol L, Lee H, Wu J (2003) Wnt5a and Wnt5b exhibit distinct activities in coordinating chondrocyte proliferation and differentiation. Development 130: 1003-1015.

Yang Y-Q, Tan Y-Y, Wong R, Wenden A, Zhang L-K, Rabie ABM (2012) The role of vascular endothelial growth factor in ossification. Int J Oral Sci 4: 64-68.

Yang Y (2009) Skeletal morphogenesis during embryonic development. Crit Rev Eukaryot Gene Expr 19: 197-218.

Yeung Tsang K, Wa Tsang S, Chan D, Cheah KS (2014) The chondrocytic journey in endochondral bone growth and skeletal dysplasia. Birth Defects Res C Embryo Today 102: 52-73.

Young N, Mikhalkevich N, Yan Y, Chen D, Zheng W-p (2005) Differential regulation of osteoblast activity by Th cell subsets mediated by parathyroid hormone and IFN- $\gamma$. J Immunol 175: 8287-8295.

Yousefi A-M, James PF, Akbarzadeh R, Subramanian A, Flavin C, Oudadesse H (2016) Prospect of stem cells in bone tissue engineering: a review. Stem Cells Int 2016: 6180487. DOI: 10.1155/2016/6180487.

Zaiss MM, Axmann R, Zwerina J, Polzer K, Gückel E, Skapenko A, Schulze-Koops H, Horwood N, Cope A, Schett G (2007) Treg cells suppress osteoclast formation: a new link between the immune system and bone. Arthritis Rheum 56: 4104-4112.

Zara JN, Siu RK, Zhang X, Shen J, Ngo R, Lee M, Li W, Chiang M, Chung J, Kwak J (2011) High doses of bone morphogenetic protein 2 induce structurally abnormal bone and inflammation in vivo. Tissue Engineering Part A 17: 1389-1399.

Zhao ZG, Xu W, Sun L, You Y, Li F, Li QB, Zou P (2012) Immunomodulatory function of regulatory dendritic cells induced by mesenchymal stem cells. Immunol Invest 41: 183-198.

Zheng ZH, Li XY, Ding J, Jia JF, Zhu P (2008) Allogeneic mesenchymal stem cell and mesenchymal stem cell-differentiated chondrocyte suppress the responses of type II collagen-reactive $\mathrm{T}$ cells in rheumatoid arthritis. Rheumatology (Oxford) 47: 22-30.

Zhou X, von der Mark K, Henry S, Norton W, Adams H, de Crombrugghe B (2014) Chondrocytes transdifferentiate into osteoblasts in endochondral bone during development, postnatal growth and fracture healing in mice. PLoS Genet 10: e1004820. DOI: 10.1371/journal.pgen.1004820.

\section{Discussion with Reviewer}

Diego Correa: Taking into consideration the pericytic phenotype of MSCs and their description as osteoprogenitors during bone formation and fracture healing (Maes et al., 2010), what would be the real contribution of such cells (as perivascular) during the engineering of bone grafts?

Authors: The idea that perictyic MSCs attach to the side of the vasculature, in a way effectively and passively migrating to the site of bone formation, is one of our favourite theories in bone tissue engineering. Although Maes et al. (2010) show that these cells undergo osteoblastic differentiation and contribute to bone formation, we believe they could also contribute to a number of crucial processes, considering the many bioactive molecules they encounter in this environment which can influence their behaviour. It would be interesting to see if they also contribute to the stabilisation of the bone marrow niche microenvironment or somehow further influence the migration of the vasculature into the centre of the cartilage template. We fully believe they contribute to bone formation, but as the field digs deeper into this area, they may find these cells play an even bigger role in bone formation.

Diego Correa: If such a phenomenon results critical, how do the authors envision to enhance it?

Authors: If it proves critical that pericytic MSCs, specifically the subset that co-migrate with the invading vasculature, are crucial for bone formation, it could be advantageous to enhance or accelerate the migration of the vasculature. Alternatively, determining what factor(s) this specific subset of MSCs is attracted to would be better; then, this(these) could be incorporated into a tissue-engineered construct or bound to a biomaterial to enhance migration of this specific MSC subtype which would have the potential to improve or accelerate bone formation.

Editor's note: The Scientific Editor responsible for this paper was Martin Stoddart. 